\title{
Do canto popular e da fala poética
}

\author{
Sara Lopes
}

p

otencializar a expressividade da voz e da fala, um dos fundamentos do trabalho vocal do ator na construção poética da representação, depende da disponibilidade e da condição de encarar este elemento de seu instrumental como parte de sua criação produção e realização em sentido intenso, eminente, absoluto -, decorrente de um profundo saber do campo em que atua e de uma técnica construída a partir do conhecimento e do treinamento do próprio corpo.

Com sua voz, o ator cria ritmo e melodia, cadências, as mais sutis modulações e inflexões, música, enfim, transformando seu texto em verdadeira partitura de tempos precisos, pausas contadas, compondo, entre sons e silêncios, a fala teatral.

Esta aproximação dos termos musicais aos procedimentos técnicos da fala denota muito claramente o quanto esta se encaminha, em seu processo de elaboração, para a complexa simplicidade da música.

A prática de elaborar a voz e a fala por meio do canto não é, então, um artifício equivocado. Principalmente quando se sabe que elementos serão identificados, reconhecidos e ex- plorados, que transposições e aplicações serão buscadas para a fala e, sobretudo, que integração terá no processo de criação.

A técnica vocal que o ator desenvolve, a partir do canto, dota-o de um controle sem ansiedade da respiração pelo conhecimento da musculatura, de uma ampliação da intensidade sonora pela maximização da função dos ressoadores, de definição e precisão na emissão, de flexibilidade e nuances nas tonalidades, de ampliação dos limites da extensão a partir dos tons médios. Em relação à fala, a sustentação de sons presente no canto resulta num equilíbrio de sonoridade, evitando a perda de rendimento tão comum aos finais de palavras e/ou frases; a silabação determinada pela melodia leva, à fala, a estabilidade do tempo e a existência de cada som; a acentuação das melodias permite a compreensão e a manutenção da cadência e do ritmo da palavra falada. A própria expressividade encontra elementos de transposição no canto. Ela supõe uma construção concreta entre melodia, ritmo e sonoridade que traça, na entoação dada pelas intenções, além da expressão em si mesma, a própria definição de um gênero ou estilo.

Sara Lopes é atriz e professora do Departamento de Artes Cênicas do Instituto de Artes da Unicamp. 
Cantar é tão diferente de falar quanto o é o dizer teatral. Apreender o sentido da voz e trabalhar o significado da fala, tendo como ponto de partida o canto, é uma forma de abordá-las como diferentes das funções utilitárias que têm no cotidiano, no uso comum. E o teatro, em seus procedimentos, não trata do cotidiano, do uso comum. Construir voz e fala por meio do canto é uma forma de construí-las teatralmente pois a fala, no teatro, aproxima-se da música.

Buscar o desenvolvimento da voz e da fala por meio do canto é procedimento capaz de levar a resultados positivos. O importante é descobrir o canto que contém os sons, as entoações, o ritmo, o movimento e a expressão da fala brasileira. Esse canto está na Canção Popular do Brasil.

\section{Entremeando modos vocais}

A estética específica da canção brasileira definiu-se pela elaboração e adoção, no período em que se estruturava e afirmava, do conceito geral de que palavras, somadas à melodia, identificam a canção e são seus principais elementos de sentido.

Manifestação artística sempre "contemporânea”, marcada de brasilidade, a palavra da canção popular cobre o mesmo período, acompanha a mesma e a própria história do teatro em fala brasileira. Nascidos do mesmo idioma e pela mesma época, a canção e o teatro firmaram-se lado a lado, no início da década dos anos 20 , alimentando-se, por temperamento, na busca permanente do novo e na procura da identidade nacional. Artes contemporâneas - o que garantia sua eficácia -, seus autores escreviam para serem ouvidos, naquele instante, por um público ávido por identificar-se.

O contato com o Teatro de Revista parece ter marcado, em definitivo, a palavra - lírica, crítica ou satírica - da Canção Popular Brasileira. Seus textos adquiriram uma tendência à encenação, à exposição de situação/ação, à localização de cenários, à proposta de enredos, à presença de personagens, ao desenvolvimento de diálogos, encaminhando-se para a figurativização pela qual "dá a impressão de que não só a situação relatada é possível, como está sendo vivida no momento exato que a canção se desenrola” (Tatit, 1996, p. 9).

Sinhô, Pixinguinha, Ary Barroso, Lamartine Babo, Benedito Lacerda, Kid Pepe, João de Barro, Custódio Mesquita, Mário Lago, Luiz Peixoto, Noel Rosa, Assis Valente, Joubert de Carvalho, Ismael Silva, Zequinha de Abreu, Heckel Tavares e tantos outros ajudaram a definir a identidade nacional do Teatro de Revista e ganharam, dele, marcas de brasilidade no contato com a cena. Suas canções, que até hoje encontram ressonância no imaginário popular e mantêm significado no entendimento do público foram, muitas delas, criadas como motivos teatrais.

O lirismo nascido do povo, a crítica e o humor, a sátira e o contato com a atualidade, que já caracterizaram o Teatro Brasileiro, na Revista, onde a língua encontrou seu meio, desatou-se e falou, têm-se mantido presentes, ao longo do tempo, na Canção Popular, que segue sendo a forma de arte que melhor entende e mais compreende o caráter brasileiro, o instrumento que o revela e traduz. Seu elemento primordial continua a ser o texto. Então ela fala. Fala do momento e como o momento fala. Em formas diversas, em linguagens renovadas, sabe se expor, criticar e criticar-se. Do povo, usa as linguagens todas e o espírito: os motes os ditos, as expressões, as gírias, as citações, a expressão da vontade, os desejos os sonhos, as desilusões, mas como quem não se leva muito a sério. Fala como fala o povo. É por ela que o povo fala. É nela que a fala do povo - pensamento e forma - se mostra, é registrada preservada e se transforma. É nela que os sons étnicos da língua encontram ressonância, espaço de acomodação e modo de existência. É, tanto quanto a fala que utiliza, reveladora da identidade e do caráter do povo.

Todo o percurso que a palavra descreveu - e continua descrevendo - no falar do nosso 
povo, com seu discurso aparente e os significados embutidos nos discursos por trás do discurso, está registrado nas canções. Elementos históricos, teóricos, técnicos e práticos que estruturam a concepção e a estética da canção, constituindo seus procedimentos e convenções, são fundamentos básicos para a criação e a recriação, na interpretação, em perspectivas contemporâneas. Nos compositores da atualidade, que entrecruzaram seus caminhos com os precursores da nossa Canção Popular ou que se debruçaram sobre sua obra, é evidente a fonte comum, a permanência de raízes profundas, brotando em novas poéticas: a tradição do texto e sua enunciação como ponto de partida para a definição do ritmo e da linha melódica. Um tal cantar pede, muito mais que um cantor, um intérprete; necessita um diseur que, mesmo sem a grande voz, explore, na reconstrução dos sentidos do texto e na figurativização, um estilo pessoal de interpretação. Trabalho muito próximo àquele do ator sobre sua fala.

\section{Da fala para a canção}

É parte do conceito de canção o entrelaçamento que liga texto e melodia. A Canção Popular Brasileira define ainda mais: tece a linha melódica e o ritmo sobre a entoação e a cadência da fala.

Seja por meio de que influência tenha vindo, é evidente a presença da enunciação do texto na definição das linhas melódicas e na determinação das formas rítmicas das canções brasileiras, permitindo "entrever em todo e qualquer tipo de canção popular, as inflexões entoativas e os sintomas gerais da fala" (Tatit, 1996, p. 6).

Esta aproximação efetiva entre canto e fala, proposta pela canção, transforma-a num instrumento bastante adequado para o estudo dos elementos e qualidades integrantes da voz e da palavra quando em função poética. A oralidade em função poética, como o canto, é uma expansão estética da fala e, como o canto, cria música pela entoação, ritmo e dinâmica pela cadência e pulsação do texto. Os sons, os ritmos e os movimentos, as melodias da Canção Brasileira, estabelecem contato entre o cantar e o falar. O exercício do canto brasileiro é meio propício ao desenvolvimento dos parâmetros ligados à voz e se presta adequadamente ao entendimento daqueles outros, referentes à fala, pois sua construção se origina na palavra.

Da fala, pois, a canção aprende a ser feita: no total aproveitamento da sonoridade particular do idioma, no tom étnico da fala, na estrutura e nas ações internas das palavras, na variedade dos temas abordados, na identidade do olhar sobre os temas, na melodia entoativa da oralidade. É importante registrar o quanto as linhas melódicas e a entoação do discurso oral, além das palavras, respondem pelo estabelecimento da cumplicidade com o ouvinte. A canção consegue garantir essa cumplicidade fundamental na relação com o público porque se constrói em função dele.

A variedade das formas, na Canção Brasileira, foi e ainda é, em grande parte, assegurada pela proposta da palavra. A diversidade dos temas, e as inúmeras maneiras de abordagem de cada um, garante que todas as formas, periodicamente, sejam retomadas. Se alguma delas se perdeu, é porque em nosso discurso, certamente, perdeu-se sua função. Modinha, canção, valsa, choro, samba, samba-canção, de enredo, exaltação ou de breque, marchinha, marcha rancho são definidos pela estrutura do texto que dá, à melodia, o ritmo da acentuação tônica das palavras, vivendo entre o som das vogais e a função percussiva das consoantes. Nessa combinação, não poucas vezes desenvolve artifícios onomatopéicos, num recurso de tradução de sentidos além das palavras. Até mesmo os movimentos originados pela alteração numérica das sílabas do texto e as modificaçôes em seus acentos, próprios da linguagem oral, encontram acomodação nas linhas melódicas e no tempo.

A escolha dos temas, a forma de abordálos, o sentido e o papel do texto em relação aos temas, são elementos de manejo constante na canção, integrando seus procedimentos, numa 
emergência do caráter e do pensamento brasileiros expressos, primeiro, em palavras.

Se a questão é existir, há um sem fim de motivações que, tendo como lastro a palavra em seu sentido próprio ou em outros significados que ela possa conter, criam formas na Canção Brasileira. Por todas elas perpassam características de uma brasilidade bem definida, perfeitamente compreendida pelos criadores de nossa canção.

\section{Da canção para a fala}

O espaço que melhor compreende e onde é exercido com mais acerto o idioma do Brasil, onde a língua tanto pode ser preservada quanto utilizada ou transformada como parte integrante do caráter do povo, onde o falar e o dizer se aliam no conhecimento dos letristas, que usam a palavra em várias funções de sentido, sempre como um componente estético, é o espaço da Canção Popular Brasileira. Nos diversos gêneros, através dos diferentes períodos, nas inúmeras formas e em todos os estilos, ela tem absorvido e incorporado qualquer influência, tem se adaptado ao falar do povo colhendo, dele, as palavras e a pulsação que, unindo-se aos temas e à visão de mundo, dão meio de existência e acomodação à fala brasileira. Todos esses elementos são organizados pela canção, ganham nela significados, concepção e estética, convenções e procedimentos, forjando uma forma de arte. Na Canção Popular, pois, podem ser encontrados os valores para o estabelecimento de conceitos e princípios relacionados às manifestações poéticas da voz e da fala, e buscados os fundamentos para uma elaboração técnica da arte de dizer, em brasileiro.

A Canção Popular aqui referida é esta mais cosmopolita, capaz de devorar e digerir tendências e influências, transformando-as em novos componentes de sua linguagem, receptiva e aberta a todas as possibilidades, de fácil acesso à divulgação e, pela possibilidade de estudo que isso oferece, documentada.
As linhas melódicas da Canção Brasileira se desenvolvem numa extensão que abarca uma oitava e mais uma sexta, na escala musical. A acomodação desta extensão num teclado vocal pode ser compreendida entre os tons graves e médios/agudos de uma voz, sem que seja preciso recorrer à região dos agudos cultivados, domínio do canto lírico. Essa característica é contrariada em raros casos de exceção, quase sempre em obras onde o compositor experimenta a transposição de uma linha de instrumento para a voz, como se dá com a maioria dos choros: escritos originalmente para uma formação instrumental, alguns ganharam versos bem depois, sem que sua concepção melódica tivesse considerado as características da voz e da fala; quando composto especialmente para a voz, sobre um texto, o mesmo choro respeita muito propriamente os parâmetros da sonoridade vocal brasileira.

Se considerarmos que uma fala natural lança mão dos tons contidos num intervalo de quinta ou sexta, em seu exercício, e que uma fala teatral percorre pouco mais de uma oitava, é possível constatar a proximidade desta com a extensão proposta pela Canção Popular: a não ser pelos limites mais extremos do agudo e do grave, convivem no mesmo espaço sonoro, vivem dos mesmos tons. Os limites da extensão, pois, são pura sabedoria da Canção Popular. Se ela não encaminha suas melodias para a região mais aguda da voz é porque a fala do Brasil, pela peculiaridade de seus sons, não encontra acomodação nela. Os tons mais agudos de uma voz dependem de uma postura na qual a emissão e a articulação se organizam na busca da sonoridade pura. O brasileiro, no agudo, perde suas variedades características e mobilidades sonoras, torna-se pouco plástico à articulação, desqualifica o tom étnico.

Assim, a região central de uma voz - seus tons médios - é o meio sonoro apropriado para o exercício da fala brasileira e o ponto de partida para a definição de seu tom.

No centro da voz as exigências da respiração são relativamente cômodas e os recursos 
de apoio ficam muito próximos do natural. O elemento que se deve apurar, então, fica por conta da emissão: sem desperdiçar a variedade sonora do idioma, construir artifícios técnicos que resultem em unidade de corpo, constância de intensidade, igualdade de rendimento sonoro e condição de amplificação no espaço por meio da definição das formas e da expansão dos recursos de ressonância. No exercício da Canção Popular, esses procedimentos afloram juntamente com a compreensão da ação sonora da palavra, de seu movimento interno, de seu encadeamento cuidadoso e da equilibrada distribuição dos sons. A articulação se resolve claramente na manutenção da pulsação, cadência e ritmo das frases e não na pronúncia isolada dos fonemas e das palavras.

Para compensar a pequena extensão que percorre, a Canção Brasileira se derrama e multiplica em infindáveis linhas melódicas. Esta característica tem sua origem e base de criação na entoação da fala, com a função de ressaltar as impressões mais contundentes de um texto, materializando sua intencionalidade ao prestarse às transformações do discurso oral. $\mathrm{O}$ que se torna mais pertinente numa fala é determinado, de maneira individual, pela interpretação pessoal de cada um. Transposto para a representação - construção material - este artifício dá margem à elaboração de linhas melódicas sempre renovadas, respeitadas as convenções de gênero e estilo. Compreender a importância e a necessidade da elaboração de melodias para a construção da expressão, na fala, é indispensável à oralidade teatral e dispõe de um farto material para pesquisa e estudo na Canção Popular.

O ritmo, esse elemento de difícil apreensão para aplicação à fala teatral, onde costuma ser confundido com velocidade ou movimento, pode bem encontrar um caminho concreto e solução poética ao apoiar-se nas modulaçōes da acentuação tônica das palavras, como faz a canção, garantindo a compreensão do texto para além das palavras, mesmo quando há aceleração. A fala não cria célula rítmica constante por não se caracterizar pela reiteração periódica de seus elementos mas, ao se valer da acentuação, vai propor pulso, estabelecer tempo, encontrando equilíbrio para os sons, mesmo na variação da dinâmica. Na canção os diferentes ritmos identificam-se a formas que, muito propriamente, criam uma tradução dos sentidos do texto. Este entendimento, e a transposição desse procedimento para a fala, dotam a composição estética da oralidade de uma especial riqueza de formas e de recursos voltados para a construção de uma poética vocal.

De fundamental importância para a concepção e para o exercício da canção é o acompanhamento instrumental e a capacidade do intérprete em se relacionar com ele. Desde sua função mais simples de apoio e duplicação da voz, até seu papel de verdadeiro antagonista, responsável por réplicas e comentários, num autêntico diálogo com a voz, ou de cúmplice, na composição harmônica com a linha do canto, garantindo a permanência do discurso nas pausas, mantendo a pulsação do momento, sua participação na estrutura da canção, bem como as modificações que sofreu, são índices de transformaçóes no pensamento estético de cada período, reveladores de perspectivas que caracterizam a trajetória da canção. $\mathrm{O}$ ator, a quem cabe a criação das linhas melódicas da fala, deve recriar sua função, valendo-se de todos os artifícios ao alcance de sua composição. Em torno dele e de sua fala tem existência uma inumerável quantidade de sons nascidos dos movimentos da cena, dos gestos, da respiração, da própria pulsação, que sublinham as falas, pontuam o texto, preenchem as pausas, construindo um percurso - interno ou externo - de acompanhamento da vocalidade, pela elaboração consciente de uma melodia cinética.

$\mathrm{O}$ ator, em seu trabalho vocal, costuma se valer, no apoio de suas concepçôes e procedimentos, de imagens pessoais, buscando o entendimento de seus mecanismos internos de produção. Combinar essas imagens aos elementos concretos, tangíveis e verificáveis que lhe dá a canção, pode auxiliá-lo no exercício da fala e do idioma, bem como na compreensão de sua 
voz que é feita de vibrações sonoras e se materializa em extensões, intensidades, durações e timbres. A adoção de um trabalho sobre o canto popular, orientado com critério, conhecimento e competência, abre a possibilidade de reconhe- cimento das características gerais da nacionalidade no processo de conhecer a sonoridade corporal de sua voz, localizar a extensão natural de sua fala, manipular a plasticidade de seu material vocal na riqueza sonora de seu idioma.

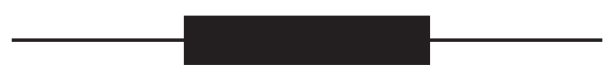

\section{Referências bibliográficas}

BANU, Georges (org). De la Parole aux Chants. Paris: Actes Sus-Papiers, 1995. Apprendre, n. 4.

DUARTE, F. J. C. A Fala e o Canto no Brasil: Dois modelos de Emissão Vocal. São Paulo: ArteUnesp, n. 10, 87-97, 1994.

LINKLATER, Kristin. Freeing the Natural Voice. New York: Drama Book Publishers, 1976.

MAMMI, Lorenzo. João Gilberto e o Projeto Utópico da Bossa Nova. São Paulo: Novos Estudos CEBRAP, n. ${ }^{\circ}$ 34, 63-70, 1992.

MATOS, Cláudia N. de; MEDEIROS, Fernanda T. de; TRAVASSOS, Elizabeth (Orgs.). Ao encontro da palavra cantada - Poesia, Música e Voz. Rio de Janeiro: 7 letras, 2001.

SANT'ANNA, Affonso Romano de. Música Popular e Moderna Poesia Brasileira. Petrópolis: Vozes, 1977.

TATIT, Luiz. A Canção: Eficácia e Encanto. São Paulo: Atual, 1986. Série Lendo. - O Cancionista: Composição de Cançôes no Brasil. São Paulo: EDUSP, 1996.

ZUMTHOR, Paul. A Letra e a Voz. São Paulo: Companhia das Letras, 1993. - Introduction à la Poésie Orale. Paris: Édition du Seuil, 1983. . Performance, recepção, leitura. São Paulo: Educ, 2000. 